\title{
COVID-19 Tanılı Yoğun Bakım Hastalarında Omega-3 Çoklu Doymamış Yağ Asitleri Desteğinin Etkileri
}

\author{
Effects of Omega-3 Polyunsaturated Fatty Acids Supplementation in Intensive Care Patients \\ with COVID-19
}

\author{
Selen Özsoy ${ }^{1}$, Mendane Saka ${ }^{2}$
}

Geliş tarihi/Received: 06.04.2021 • Kabul tarihi/Accepted: 14.08.2021

\section{ÖZET}

SARS-CoV-2 adı ile ilk kez bildirilen ve COVID-19 olarak adlandırılan yeni tip koronavirüsün neden olduğu salgın hastalık kısa sürede yayılım göstererek küresel bir sağlık sorunu haline gelmiş ve Dünya Sağlık Örgütü salgını bir pandemi olarak nitelendirmiştir. COVID-19 hastalığının yönetimi için önerilen spesifik bir antiviral tedavi bulunmamaktadır. Hastalarda immün yanıtı hedefleyen ve sitokin firtınasını azaltmaya yönelik alternatif tedavi yöntemlerinin geliştirilmesi, hastalığa yanıtın iyileştirilmesinde önemli bir stratejidir. Hastalıktan korunmada ve hastalığın yönetimi sürecinde konağın bağışıklık sisteminin güçlendirilmesini hedefleyen stratejiler, virüsle savaşmada ve hastalık etkisinin azaltılmasında önemlidir. Balık yağı kaynaklı Eikozapentaenoik Asit (EPA) ve Dokozahekzaenoik Asit (DHA) biyolojik olarak güçlü özellik taşır. Omega-3 Çoklu Doymamış Yağ Asitleri (PUFA) güçlü immünmodülatör aktiviteye sahip olup, diyetin balık yağı ile zenginleştirilmesi monosit ve nötrofil kemotaksisinde azalmaya neden olur, proinflamatuvar sitokin üretimini azaltır ve antiinflamatuvar etkiler gösterir. Kritik hastalarda yapılan çalışmalar, enteral ve parenteral omega-3 PUFA takviyelerinin sitokin üretimini azalttığını göstermiştir. Sitokinler üzerindeki bu etkileri nedeni ile omega-3 PUFA, akut ve kronik inflamasyon durumlarında ve uygunsuz şekilde aktive edilmiş olan immün yanıtın azaltılmasında kullanılmaktadır. COVID-19 hastalığının yönetimi ile ilgili yayınlanan beslenme kılavuzları, balık yağı kullanımının hastalığın yönetiminde potansiyel yararlı etkileri olabileceğini bildirmiştir. Bu derleme yazıda, COVID-19 ile omega-3 PUFA arasındaki ilişki incelenmiş ve COVID-19 hastaları için omega-3 PUFA'ların önemi ele alınmıştır.

Anahtar kelimeler: SARS-COV 2, COVID-19, yoğun bakım ünitesi, balık yağl, beslenme

\begin{abstract}
The epidemic caused by the new type of coronavirus, which was first reported as SARS-CoV-2 and called COVID-19, spread in a short time and became a global health problem and the World Health Organization described the epidemic as a pandemic. There is no specific antiviral therapy recommended for the management of COVID-19 disease. Developing alternative treatment methods that target immune response and reduce cytokine storm in patients is an important strategy in improving disease response. Strategies that aim to strengthen the immune system of the host in the prevention and management of the disease are important in fighting the virus and reducing the effect of the disease. Eicosapentaenoic Acid (EPA) and Docosahexaenoic Acid (DHA) from fish oil are biologically strong. Omega-3 Polyunsaturated Fatty Acids (PUFAs) have strong immunomodulatory activity, and enrichment of the diet with fish oil causes a decrease in monocyte and
\end{abstract}

1. İletişim/Correspondence: Ankara Şehir Hastanesi, Klinik Nütrisyon Ünitesi, Ankara, Türkiye

E-posta: selenaksoy_@outlook.com•• ㄴ https://orcid.org/0000-0003-3583-3216
2. Başkent Üniversitesi, Sağllk Bilimleri Fakültesi, Beslenme ve Diyetetik Bölümü, Ankara, Türkiye • $\odot$ https://orcid.org/0000-0002-5516-426X 
neutrophil chemotaxis, decreases proinflammatory cytokine production and exhibits anti-inflammatory effects. Studies in critically ill patients have shown that enteral and parenteral omega-3 supplements reduce cytokine production. Because of these effects on cytokines, omega-3 PUFA is used in acute and chronic inflammation situations and in reducing the immune response that is inappropriately activated. Published dietary guidelines on the management of COVID-19 disease have reported that the use of fish oil can have potential beneficial effects in the management of the disease. In this review, the association between COVID-19 and omega-3 PUFAs was investigated and the importance of omega-3 PUFAs for patients with COVID-19 was discussed.

Keywords: SARS-COV 2, COVID-19, intensive care unit, fish oil, nutrition

\section{GİRIŞ}

Yeni tip bir koronavirüsün neden olduğu hastalık Aralık 2019'da Çin'in Wuhan Şehrindeki yetkililer tarafından ilk kez SARS-CoV-2 adı ile bildirilmiştir (1). Mart 2020'de Çin dışındaki vaka sayısındaki hızlı artış nedeni ile Dünya Sağlık Örgütü salgını pandemi olarak nitelendirmiştir (2). COVID-19 hastalığının patogenezini temel olarak bağışıklık ve inflamatuvar süreçlerin bozulması oluşturmaktadır. Hastalık sürecinde vakalarda enzim, inflamasyon belirteci ve pıhtılaşma ile ilgili göstergelerin seviyeleri artmaktadır. Şiddetli vakalarda dispne ile lenfopeni, hipoalbüminemi, alanin aminotransferaz, aspartat aminotransferaz (AST), C-reaktif protein (CRP), D-dimer, interlökin-6 (IL-6), eritrosit sedimantasyon hızl, serum amiloid A, serum ferritin, laktik dehidrojenaz (LDH), a-hidroksibütirat dehidrojenaz ve fibrinojen seviyeleri artışı bildirilmiştir. IL-6, CRP, LDH, AST, D-dimer ve fibrinojen seviyelerinin hastalığın ilerlemesi ve tedavisi sırasında dinamik olarak değiştiği gösterilmiştir. Klinik raporlar hem hafifhem de şiddetli hastalık durumunun dolaşımdaki lökosit alt kümelerinde ve özellikle IL-6, IL-1 $\beta$, IL-10, Tümör Nekroz Faktör- $\alpha$ (TNF- $\alpha$ ), Granülosit Makrofaj Koloni Uyarıcı Faktör, İnterferon- $\gamma$ (IFN- $\gamma$ ) ile İndüklenen Protein 10 (IP-10); IL-17, Monosit Kemoatraktan Protein-3 ve IL-1 Reseptör Antagonisti olmak üzere sitokin sekresyonunda önemli değişikliklere neden olduğunu göstermektedir (3-6). Ağır COVID-19 hastalarının dolaşımlarında proinflamatuvar sitokin ve nötrofil saylarının orta dereceli vakalara göre daha yüksek olduğu ve serum IL-6, IL-10, IL-2, TNF-a, IFN- $\gamma$ seviyelerinde artış olduğu bildirilmiştir.
$\mathrm{T}$ hücrelerinin, özellikle sitotoksik $\mathrm{T}$ hücrelerinin $($ CD8 $+\mathrm{T})$ ise mutlak saylları hemen hemen tüm hastalarda anlamlı olarak azalmış ve şiddetli vakalarda sayının, orta dereceli vakalara kıyasla daha fazla azaldığı bildirilmiştir $(7,8)$. Sitokin ortamı, yüksek IL-6 ekspresyonu ile inflamatuvar CD14+ ve CD16+ monositlerini indükleyerek inflamasyonu hızlandırır. Şiddetli COVID-19 hastalarında çok sayıda patojenik yardımcı T-1 hücreleri ve inflamatuvar monositler pulmoner dolaşıma girer ve hastaların akciğerlerinde ciddi inflamatuvar hücre infiltrasyonuna sebep olur. $\mathrm{Bu}$ durum akciğerin fonksiyonunun bozulmasina neden olabilir (9).

COVID-19 pandemisi için önerilen tıbbi tedavi protokolü; semptomatik tedavi, ikincil enfeksiyonun önlenmesi ve antiviral tedaviden oluşmaktadır. Hastalığın yönetiminde antiviral tedavinin etkinliği ise henüz tanımlanmamıştır (10). Hastalığın ilerlemiş evrelerinin yönetimi için yoğun bakıma ihtiyaç vardır. Akut Solunum Sıkıntısı Sendromu (ARDS) tedavisi ile ilgili olarak, akciğer hasarının patofizyolojisi hakkında biriken bilgi, klinisyenleri solunum yetmezliği ile başa çlkma stratejilerini gözden geçirmeye teşvik etmiştir. Oksijen tedavisi, solunum yetmezliği yönetiminde ilk adımdır. Oksijen tedavisine yanıt vermeyen solunum yetmezliği vakalarında non-invaziv ve invaziv mekanik ventilasyon (MV) gerekli olabilir (11). Sitokin fırtınasının yoğunluğunu tetikleyen mekanizmaların daha iyi anlaşılması, COVID-19 hastalığının farklı aşamalarında tedavi stratejilerinin geliştirilmesi ve dünya çapındaki bu halk sağlığı tehdidine yanıtın iyileştirilmesini hedeflemektedir. Virüsle savaşmak 
için konak hazırlığı, COVID-19 şiddetinden kaçınmak için önemli bir stratejidir. Beslenme alışkanlıklarının ve beslenme durumunun bağışıklık yanıtı üzerindeki etkileri viral solunum yolu enfeksiyonlarının önlenmesi ve yönetiminde önemlidir. Yetersiz beslenme, bağışıklık sisteminde değişikliklere neden olarak bağışıklık tepkisini azaltır, SARS-CoV-2 gibi enfeksiyonlara duyarlılığı ve virülansı arttırır (12). Başta bağışıklık sisteminde önemli rol oynayanlar olmak üzere besin ögelerinin optimum alımı, yeterli ve dengeli bir diyetle sağlanmalıdır. Enfeksiyon ve diğer stres etkenleri vücutta mikro besin ögeleri düzeylerini azaltabileceğinden, enfeksiyona yakalanma riskinin ve sonuçlarının azaltılması için, bazı mikro besin ögelerinin alımı diyet ile önerilen miktarların üzerine çıkabilir. Doğal biyoaktif bileşikler, SARS-CoV2'nin neden olduğu inflamatuvar yanıtı azaltabilir ve hastaların beslenme yönetiminde potansiyel yararlı araçlardır $(12,13)$. Bu nedenle Avrupa Klinik Beslenme ve Metabolizma Derneği (ESPEN) SARSCoV-2 enfeksiyonlu bireylerin nütrisyonel yönetimi için yayınladığı kılavuzda, COVID-19 hastalarındaki mikro besin ögelerinin değerlendirilmesinde $\mathrm{A}$, D, B, C vitaminleri ile omega-3 PUFA'nin yanı sira, selenyum, çinko ve demir gibi minerallerin de dikkate alınması gerektiğini vurgulamıştır (14). Bu derleme yazıda, omega-3 PUFA ile COVID-19 arasındaki ilişki incelenmiş ve COVID-19 hastaları için omega-3 PUFA'ların önemi ele alınmıştır.

Vücutta inflamasyona neden olan inflamatuvar hücreler ve bağışıklık sağlayan hücrelerin yağ asidi bileşimi, diyet ile tüketilen yağ asidi bileşiminden etkilenir. Bu hücrelerdeki farklı tipteki PUFA oranı kolaylıkla değiştirilir. İnflamatuvar yanıta dahil olan hücrelerin yağ asidi bileşiminin değiştirilmesi, inflamasyonun peptid aracilarının (adezyon molekülleri, sitokinler vb.) üretimini etkiler. Bu nedenle, inflamasyon tepkisine dahil olan hücrelerin yağ asidi bileşimi, hücrelerin işlevlerini etkiler. Uzun zincirli yağ asitleri zar akışkanlığını, hücre sinyalizasyonunu ve lipid medyatör üretim modelini değiştirerek çeşitli mekanizmalarla inflamasyonu etkiler. Araşidonik asitten (AA), üretilen eikosanoidler inflamatuvar yanıt gelişiminde rol oynar. İnflamasyon ve bağışıklığın düzenlenmesinde önemli rollere sahip olan AA prostaglandinlerin, lökotrienlerin ve ilgili bileşiklerin öncüsüdür. Yağ asitleri arasında en güçlü immünomodülatör aktiviteye sahip olan yağ türü omega-3 PUFA'dır. Hem doğal hem de kazanılmış bağışılklığın bileşenleri, temel inflamatuvar aracıların üretimi dâhil, omega-3 PUFA'dan etkilenebilir. Balık yağı EPA ve DHA içerir. Balık yağından zengin beslenme, hücre zarlarında AA'in EPA ile kısmen yer değiştirmesine neden olur. Hücre membranında EPA ve DHA'nın artması ve araşidonik asit içeriğinin azalması, eikosanoidlerin ve AA türevi aracıların üretiminin azalmasina yol açar. Diyetin omega-3 PUFA ile zenginleştirilmesi monosit ve nötrofil kemotaksisi ile proinflamatuvar sitokinlerin üretimini azaltmaktadır. Bu tür omega-3 PUFA ile indüklenen etkiler, akut ve kronik inflamasyon için bir tedavi olarak ve uygunsuz bir şekilde aktive edilmiş bir immün tepkiyi içeren bozukluklar için kullanılabilir. Bu durum omega-3 PUFA'larının antiinflamatuvar etkileri nedeni ile inflamatuvar bileşenli bozukluklarda terapötik ajanlar olarak faydalı olabileceğini düşündürmektedir $(15,16)$.

Sepsis veya septik şok tanısı almış kritik hastalarda enteral ve parenteral omega-3 balık yağı takviyelerinin sitokin üretimini azalttığı gösterilmiştir (17). Ciddi sepsis tanılı yoğun bakım ünitesi (YBÜ) hastalarına 5 gün boyunca günlük $100 \mathrm{~mL}$ balık yağı bazlı lipit emülsiyonu takviyesinin, hastalığın yönetimini iyileştirebileceği bildirilmiştir (18). Lu et al. (19) tarafından yapılan meta-analiz çalışmada, sepsis veya septik şok tanısı almış kritik hastalığı olan yetişkin hastalarda parenteral veya enteral omega-3 yağ asidi takviyesinin YBÜ kalış süresini ve MV süresini azalttığı (sırasıyla -3.79 gün ve -2.27 gün) gösterilmiştir. Sepsis tanılı parenteral beslenen hastalara omega-3 yă asidi takviyesinin etkilerini inceleyen farklı metaanalizde, takviyenin 28 günlük mortaliteyi, YBÜ kalış süresi ve hastanede kalış süresini anlamlı olarak azalttığı gösterilmiştir (sırasıyla rölatif risk: 0.77, $\mathrm{p}=0.04$; -3.10 gün, $\mathrm{p}=0.04$; -3.12 gün, $\mathrm{p}<0.001$ ) (20). Omega-3 yağ asidinin septik hastalar üzerindeki 
etkilerinin araştırıldığı farklı bir meta-analizde ise omega-3 yağ asidi desteğinin mortalite ve infeksiyöz komplikasyonları etkilemezken, MV süresini anlamlı olarak azalttığı bildirilmiştir ( $p<0.001)$ (21). İbrahim et al. (22) tarafından yapılan meta-analiz çalışmada, YBÜ’nde kritik hastalığı olan septik hastalara enteral omega-3 balık yağı verilmesinin organ yetmezliği ve hemodinamik yetmezlik üzerine etkilerinin araştırıldığı bir çalışmada takviyenin, hastalarda Sepsis ile ilişkili Organ Yetmezliği Değerlendirmesi (SOFA) skorunu ve YBÜ kalış süresini azaltarak organ fonksiyonunu iyileştirdiği (sırasıyla $\mathrm{p}<0.05 ; \mathrm{p}=0.03$; $\mathrm{p}=0.019$ ) bildirilmiştir. Grau-Carmona et al.'un (23) yaptığı çalışmada parenteral beslenen tıbbi ve cerrahi kritik hastalarda omega-3 PUFA uygulanmasinin, nozokomiyal enfeksiyon prevalansını anlamlı olarak azalttığı ( $p=0.035)$ ve enfeksiyonsuz süreci anlamlı olarak uzattığı $(\mathrm{p}=0.03)$ bildirilmiştir. Palmer et al.'un (24) yaptığı bir meta-analiz çalışmada yetişkin YBÜ hastalarına omega-3 ile zenginleştirilmiş parenteral beslenme verilmesinin hastanede kalıs süresini anlamlı olarak azalttığı bildirilmiştir. Kritik hastalarda enteral beslenmede omega-3 yağ asitlerinin değerlendirildiği bir meta-analizde, enteral balık yağı desteğinin ARDS'li hastalarda 28 günlük mortalite, YBÜ, hastanede kalış süresi ve MV süresini anlamlı olarak azalttığı bildirilmiştir (25). Naghibi et al. (26) tarafindan 2020 yılında yapılan bir çalışmada MV uygulanan hastalarda inflamasyon kaynaklı deliryumun önlenmesinde omega-3 yağ asitlerinin deliryum süresi, YBÜ kalış süresi ve MV süresini anlamlı olarak azalttığı (sirasıyla: $p=0.032$; $\mathrm{p}=0.02 ; \mathrm{p}=0.042$ ) bildirilmiştir. Kritik hastalarda parenteral balık yağı içeren lipit emülsiyonlarının etkilerinin araştırıldığı bir meta-analizde balık yağı içeren emülsiyonların uygulanmasının, mortalite ve MV süresinde azalmaya doğru bir eğilim gösterdiği (sırasıyla: $\mathrm{p}=0.08 ; \mathrm{p}=0.17$ ) bildirilmiştir (27). ARDS tanılı yetişkin hastalarda enteral omega-3 yağ asiti takviyelerinin değerlendirildiği bir meta-analizde; omega-3 yağ asidi grubunda parsiyel arteriyel oksijen $\left(\mathrm{PaO}_{2}\right)$ basincinın, solunan havadaki fraksiyone $\mathrm{O}_{2}$ 'ye $\left(\mathrm{FiO}_{2}\right)$ oranının 4. günde anlamlı olarak arttığı gösterilmiştir ( $p=0.002)$ (28). Sepsisli kritik hastalarda omega-3 yağ asidi desteğinin hastane maliyetine etkisini değerlendirmek amacı ile 12 randomize kontrollü çalışmanın incelendiği bir araştırmada, omega-3 yağ asidi takviyesi alan septik hastaların ortalama YBÜ maliyetleri daha düşük bulunmuştur (29).

ESPEN YBÜ hastaları için 2019 yılında yayınladığı kılavuzda, YBÜ’nde yatmakta olan ve parenteral beslenen hastalara EPA ve DHA (balık yağı dozu: 0.1-0.2 g/kg/gün) ile zenginleştirilmiş parenteral lipid emülsiyonları uygulanabileceğini ve omega-3 yağ asitleri ile zenginleştirilmiş enteral nütrisyon verilebileceğini bildirmiştir (30).

COVID-19 pandemisi için yayınlanan özel kılavuzlar da balık yağı kullanımının potansiyel yararları olabileceğini bildirmiştir. Yayınlanan bir yoğun bakım kılavuzunda YBÜ'nde yatmakta olan ARDS'li COVID-19 hastalarının beslenme yönetiminde omega-3 yağ asitleri ile zenginleştirilmiş enteral beslenmenin tercih edilmesi önerilmektedir. Parenteral beslenen hastalarda ise balık yağıyla zenginleştirilmiş intravenöz yağ emülsiyonları verilmesi önerilmektedir (31). Amerika Parenteral ve Enteral Beslenme Derneği (ASPEN) COVID-19 nedeni ile YBÜ yatmakta olan kritik hastalarda klinik sonuçları iyileştirmek amacıyla standart beslenme veya beslenme desteğinin bir parçası olarak mikro besin ögeleri takviyeleri, probiyotikler ve diğer farmakolojik ajanların yanı sıra krom, balık yağları ve antioksidanların spesifik kullanımları ile parenteral balık yağı içeren lipid kullanımının viral klirens ile klinik sonuçları iyileştirebileceğini ve COVID-19 akut inflamatuvar fazı sırasında karışı lipid emülsiyonlarının düşünülmesi gerektiğini bildirmiştir (32,33). ESPEN kanıtlar yetersiz olmakla birlikte enteral omega-3 yağ asitlerinin kullanımının oksijenasyonu iyileştirebileceğini bildirmiştir (14).

Enteral ve Parenteral Beslenme Kılavuzlarının balık yağı (omega-3) kullanımı açısından genel önerileri aşağıda yer alan tabloda gösterilmiştir (14,30,32-37). 
Tablo 1. Enteral ve Parenteral Beslenme Kılavuzlarının balık yağı (omega-3) kullanım önerileri

- Omega-3 ile zenginleştirilmiş enteral nütrisyon ürünlerinin yüksek dozları bolus uygulama ile verilmemelidir. Öneri derecesi: B (\%91 uzlaşı).

- Beslenme dozları dahilinde omega-3 balık yağı ile zenginleştirilmiş enteral nütrisyon Yoğun Bakım Ünitesi Klinik Beslenme Klavuzu: 2019 verilebilir. Öneri derecesi: 0 güçlü fikir birliği (\%95 uzlaşı).

- Yüksek dozlarda omega-3 ile zenginleştirilmiş enteral ürünler rutin olarak verilmemelidir. Öneri derecesi: B (\%90 uzlaşı)

- Parenteral nütrisyon alan hastalarda EPA + DHA (balık yağı dozu 0.1-0.2 g/kg/gün) ile zenginleştirilmiş parenteral lipid emülsiyonları sağlanabilir. Öneri derecesi: 0: güçlü fikir birliği (\%100 uzlaşı) (30).

Yoğun Bakım Ünitesi • EPA ve DHA’nın lipid emülsiyonlarına eklenmesi, hücre zarları ve inflamatuvar süreçler Parenteral Beslenme üzerinde kanıtlanabilir etkilere sahiptir (B düzeyi). Balık yağı ile zenginleştirilmiş lipit ESPEN Kllavuzu :2009 emülsiyonları kritik hastalarda kalışsüresini kısaltabilir (B düzeyi) (34).

- İmmün modüle edici ürünler (arginin, nükleotidler ve omega-3 yağ asitleri ile zenginleştirilmiş ürünler) elektif üst gastrointestinal cerrahi hastalarında (A düzeyi), hafif sepsisi olan hastalarda

Yoğun Bakım Ünitesi Enteral Beslenme Kllavuzu: 2006

SARS-CoV-2

enfeksiyonlu bireylerin nutrisyonel yönetimi için kılavuz: 2020

ASPEN Bakımı Gerektiren COVID-19 Hastalığ Olan Hastada Beslenme Tedavisi

\section{Kanada Klinik}

KANADA Uygulama Yönergeleri $-2015$
ASPEN: 2016

(B düzeyi) ve travma hastalarında (A düzeyi) standart enteral ürünlerden üstündür.

- ARDS’li hastalar omega-3 yağ asitleri ve antioksidanlarla zenginleştirilmiş EN almalıdır. (B düzeyi)

- Ağır sepsisli hastalarda immün modüle edici formüller zararlı olabilir ve bu nedenle önerilmez (B düzeyi) (35).

- COVID-19 hastalarındaki mikro besin ögelerinin değerlendirilmesinde A, D, B, C vitaminleri ile omega-3 PUFA yanı sıra, selenyum, çinko ve demir dikkate alınmalıdır.

- ESPEN kanitlar yetersiz olmakla birlikte enteral omega-3 yağ asitlerinin kullanımının oksijenasyonu iyileştirebileceğini bildirmiştir (14).

- ARDS ve şiddetli akut akciğer hasarı olan hastalarda anti-inflamatuvar lipid profili (örn., omega-3 balık yağı, hodan yağı) ve antioksidanlar ile karakterize edilen bir enteral formülasyonun rutin kullanımına ilişkin şu anda bir öneride bulunamayacağını bildirmiştir. (Kanıt Kalitesi: Düşük-Çok Düşük).

- Alternatif intravenöz lipid emülsiyonları (SMOF lipit; MCT, zeytinyağı ve balık yağı); soya bazlı intravenöz lipid emülsiyonlarına göre avantaj sağlayabilir.

- Enteral nütrisyon tedavisi gerektiren postoperatif cerrahi YBÜ hastalarında immün modüle edici formülün (hem arginin hem de balık yağlarını içeren) rutin kullanımı önerilmiştir.

- Travmatik beyin yaralanması olan hastalarda arginin içeren immün modüle edici formülasyonların ya da standart enteral formülle EPA/DHA takviyesinin kullanılması önerilmiştir (36).

- COVID-19 nedeni ile YBÜ’nde yatmakta olan kritik hastalarda klinik sonuçları iyileştirmek amacıyla standart beslenme veya beslenme desteğinin bir parçası olarak mikro besin takviyeleri, probiyotikler ve diğer farmakolojik ajanların yanı sıra krom, balık yağları ve antioksidanların spesifik kullanımları ile parenteral balık yağı içeren lipid kullanımının viral klirensi ve/veya klinik sonuçları iyileştirebileceği ve COVID-19 akut inflamatuvar fazı sırasında karışık lipid emülsiyonlarının düşünülmesi gerektiği bildirilmiştir (32,33).

- 4.1 b.(i): Akut Akciğer Yaralanması ve ARDS hastalarında balık yağları, boraj yağları ve antioksidan içeren enteral formülün kullanılması 3 seviye 1 çalışma ve 5 seviye 2 çalışmaya dayanarak düşünülmelidir.

- 4.1 b.(ii): Kritik hastalarda balık yağlarının tek başına takviyesi konusunda tavsiyede bulunmak için yeterli veri yoktur (37).

ARDS: Akut Solunum Stkıntısı Sendromu; ASPEN: Amerikan Parenteral ve Enteral Beslenme Derneği, DHA: Dokosahekzaenoik Asit; EPA: Eikosapentaenoik Asit; ESPEN: Avrupa Klinik Beslenme ve Metabolizma Derneği; MCT: Orta zincirli yağ asitleri; SMOF: Soya fasulyesi yağı, orta zincirli yağ asitleri, zeytin yağ̆ ve balık yağı emülsiyonu, YBÜ: Yoğun Bakım Ünitesi 
COVID-19 ile enfekte YBÜ hastaları ile yürütülen çift kör klinik bir araştırmada, hastalara enteral beslenme yoluyla vücut ağırlığı başına günlük 30 kkal olmak üzere yüksek proteinli enteral ürün verilerek katılımcılar müdahale ve kontrol grubu olmak üzere iki gruba ayrılmıştır. Müdahale grubuna YBÜ yatışının ilk 24 saatinden sonra 2 hafta süreyle, enteral beslenmeye ek olarak $400 \mathrm{mg}$ EPA ve 200 mg DHA içeren günlük 1000 mg omega-3 kapsülü verilmiştir. Çalışma sonunda müdahale grubunda 1 aylık sağ kalım oranının, kontrol grubuna göre anlamlı olarak daha yüksek olduğu bildirilmiştir $(p=0.003)$. Ayrıca müdahale grubunda kontrol grubuna göre kan üre azotu ve kreatinin düzeylerinin daha düşük, çıkarılan idrar miktarının daha fazla, arteriyel $\mathrm{pH}$ ve bikarbonat seviyelerinin anlamlı olarak daha yüksek olduğu bulunmuştur. Çalışma sonunda müdahale grubunda potasyum seviyesi, kontrol grubuna kıyasla anlamlı olarak azalmıştır $(\mathrm{p}=0.01)$ (38). Farklı bir çalışmada ise COVID-19 enfeksiyonuna sahip 100 hastanın hastaneye kabulleri sırasında alınan kan örneklerinden Omega-3 İndeksi (O3I) analiz edilmiştir. Çalışma sonunda istatistiksel olarak anlamlılık kriterlerini karşılamamakla birlikte, düşük O3I düzeyleri ile yüksek ölüm riski arasında güçlü eğilim olduğu ve daha yüksek O3I'nin COVID-19'dan ölüm riskini azaltabileceği bildirilmiştir (39).

\section{SONUÇ}

Tüm dünyayı etkisi altına alan COVID-19 salgınının kritik komplikasyonlarının azaltılması ve hastalığın yönetiminde etkin tedavi stratejilerinin geliştirilmesine küresel çapta ivedilikle ihtiyaç duyulmaktadır. COVID-19 nedeni ile YBÜ’nde yatmakta olan hastaların yönetimi konusunda yayınlanan kllavuzlar ve literatür verileri bütüncül olarak değerlendirildiğinde, beslenme kılavuzları omega-3 balık yağı kullanımının hastalığın neden olduğu inflamatuvar süreci azaltarak yararlı etkiler gösterebileceğini öngörmektedir. Bununla beraber halk sağlığının korunması ve sağlığın sürdürülmesi göz önüne alındığında hastalıktan korunma ve tedavi sürecinde omega-3 kullanımının etkilerini değerlendiren daha fazla çalışmaya ihtiyaç vardır.
Çıkar çatışması - Conflict of interest: Yazarlar çıkar çatışması olmadığını beyan ederler. - The authors declare that they have no conflict of interest.

Yazarlık katkısı - Author contributions: Çalışmanın tasarımı: SÖ; İlgili literatürün taranmast: SÖ; Makale taslağınin oluşturulmast: SÖ, MS; İçerik için eleştirel gözden geçirme: SÖ, MS; Yayınlanacak versiyonun son onayl: SÖ, MS - Study design: SÖ; Literature review: SÖ; Draft preparation: SÖ, MS; Critical review for content: SÖ, MS; Final approval of the version to be published: SÖ, MS.

\section{KAYNAKLAR}

1. World Health Organization. World Health Organization Coronavirus disease 2019 (COVID-19) Situation Report 94 [Internet]. Published: 2020 Apr 23. [cited 04/04/2021]. Available from: https://www.who.int/docs/defaultsource/coronaviruse/situation-reports/20200423-sitrep94-covid-19.pdf.

2. World Health Organization. Coronavirus disease (COVID-19) pandemic [Internet]. [cited 04/04/2021]. Available from: https://www.euro.who.int/en/healthtopics/health-emergencies/coronavirus-covid-19/novelcoronavirus-2019-ncov.

3. Chen G, Wu D, Guo W, Cao Y, Huang D, Wang H, et al. Clinical and immunological features of severe and moderate coronavirus disease 2019. J Clin Invest. 2020;130(5):2620-9.

4. Zheng Z, Peng F, Xu B, Zhao J, Liu H, Peng J, et al. Risk factors of critical \& mortal COVID-19 cases: A systematic literature review and meta-analysis. J Infect. 2020;81(2):e16-25.

5. Wang $\mathrm{H}$, Luo S, Shen Y, Li M. Multiple enzyme release, inflammation storm and hypercoagulability are prominent indicators for disease progression in COVID-19: a multi-centered, correlation study with CT imaging score [Internet]. Published: 24 Mar 2020 [cited 2021 Feb 3]. Available from: http://dx.doi.org/10.2139/ ssrn.3544837.

6. Wang J, Jiang M, Chen X, Montaner LJ. Cytokine storm and leukocyte changes in mild versus severe SARSCoV-2 infection: Review of 3939 COVID-19 patients in China and emerging pathogenesis and therapy concepts. J Leukoc Biol. 2020;108(1):17-41.

7. Liu J, Li S, Liu J, Liang B, Wang X, Wang H, et al. Longitudinal characteristics of lymphocyte responses and cytokine profiles in the peripheral blood of SARSCoV-2 infected patients. EBioMedicine. 2020;55:102763. 
8. Han H, Ma Q, Li C, Liu R, Zhao L, Wang W, et al. Profiling serum cytokines in COVID-19 patients reveals IL-6 and IL-10 are disease severity predictors. Emerg Microbes Infect. 2020;9(1):1123-30.

9. Zhou Y, Fu B, Zheng X, Wang D, Zhao C, qi Y, et al. Pathogenic $\mathrm{T}$ cells and inflammatory monocytes incite inflammatory storm in severe COVID-19 patients. Natl Sci Rev. 2020;nwaa041.

10. Stachowska E, Folwarski M, Jamioł-Milc D, Maciejewska D, Skonieczna-Żydecka K. Nutritional support in Coronavirus 2019 disease. Medicina (Kaunas). 2020;56(6):289.

11. Cascella M, Rajnik M, Cuomo A, Dulebohn SC, Napoli RD. Features, Evaluation, and Treatment of Coronavirus. Features, Evaluation, and Treatment of Coronavirus (COVID-19) In: StatPearls [Internet]. Treasure Island (FL): StatPearls Publishing; 2021 Jan-. Available from: https://www.ncbi.nlm.nih.gov/books/NBK554776/.

12. Morais AHA, Aquino JS, Silva-Maia JKD, Vale SHL, Maciel BLL, Passos TS. Nutritional status, diet and viral respiratory infections: perspectives for SARS-CoV-2. Br J Nutr. 2021;125(8):851-62.

13. Fernández-Quintela A, Milton-Laskibar I, Trepiana J, Gómez-Zorita S, Kajarabille N, Léniz A, et al. Key Aspects in nutritional management of COVID-19 Patients. J Clin Med. 2020;9(8):E2589.

14. Barazzoni R, Bischoff SC, Breda J, Wickramasinghe K, Krznaric Z, Nitzan D, et al. ESPEN expert statements and practical guidance for nutritional management of individuals with SARS-CoV-2 infection. Clin Nutr. 2020;39(6):1631-8.

15. Calder PC. Polyunsaturated Fatty Acids, Inflammation, and Immunity. Lipids. 2001;36:9.

16. Calder PC. Omega-3 fatty acids and inflammatory processes. Nutrients. 2010;2(3):355-74.

17. Mayer K, Gokorsch S, Fegbeutel C, Hattar K, Rosseau S, Walmrath D, et al. Parenteral nutrition with fish oil modulates cytokine response in patients with sepsis. Am J Respir Crit Care Med. 2003;167(10):1321-8.

18. Khor BS, Liaw SJ, Shih HC, Wang LS. Randomized, double blind, placebo-controlled trial of fish-oil-based lipid emulsion infusion for treatment of critically ill patients with severe sepsis. Asian J Surg. 2011;34(1):1-10.

19. Lu C, Sharma S, McIntyre L, Rhodes A, Evans L, Almenawer $S$, et al. Omega-3 supplementation in patients with sepsis: a systematic review and metaanalysis of randomized trials. Ann Intensive Care. 2017;7(1):58.

20. Mo Y, Hu X, Chang L, Ma P. [The effect of $\omega$-3 fatty acid supplementation in parenteral nutrition on the outcome of patients with sepsis: a systematic review and meta-analysis]. Zhonghua Wei Zhong Bing Ji Jiu Yi
Xue. 2014;26(3):142-7.

21. Tao W, Li PS, Shen Z, Shu YS, Liu S. Effects of omega-3 fatty acid nutrition on mortality in septic patients: a meta-analysis of randomized controlled trials. BMC Anesthesiol. 2016;16(1):39.

22. Ibrahim ES. Enteral nutrition with omega-3 fatty acids in critically ill septic patients: A randomized doubleblinded study. Saudi J Anaesth. 2018;12(4):529-34.

23. Grau-Carmona T, Bonet-Saris A, García-de-Lorenzo A, Sánchez-Alvarez C, Rodríguez-Pozo A, Acosta-Escribano $\mathrm{J}$, et al. Influence of n-3 polyunsaturated fatty acids enriched lipid emulsions on nosocomial infections and clinical outcomes in critically ill patients: ICU lipids study. Crit Care Med. 2015;43(1):31-9.

24. Palmer AJ, Ho CK, Ajibola O, Avenell A. The role of $\omega-3$ fatty acid supplemented parenteral nutrition in critical illness in adults: a systematic review and meta-analysis. Crit Care Med. 2013;41(1):307-16.

25. Kristine Koekkoek W, Panteleon V, van Zanten AR. Current evidence on $\omega$-3 fatty acids in enteral nutrition in the critically ill: A systematic review and metaanalysis. Nutrition. 2019;59:56-68.

26. Naghibi T, Shafigh N, Mazloomzadeh S. Role of omega-3 fatty acids in the prevention of delirium in mechanically ventilated patients. J Res Med Sci. 2020;25:10.

27. Manzanares W, Dhaliwal R, Jurewitsch B, Stapleton RD, Jeejeebhoy KN, Heyland DK. Parenteral fish oil lipid emulsions in the critically ill: a systematic review and meta-analysis. JPEN J Parenter Enteral Nutr. 2014;38(1):20-8.

28. Zhu D, Zhang Y, Li S, Gan L, Feng H, Nie W. Enteral omega-3 fatty acid supplementation in adult patients with acute respiratory distress syndrome: a systematic review of randomized controlled trials with metaanalysis and trial sequential analysis. Intensive Care Med. 2014;40(4):504-12.

29. Kyeremanteng K, Shen J, Thavorn K, Fernando SM, Herritt B, Chaudhuri D, et al. Cost analysis of Omega-3 supplementation in critically ill patients with sepsis. Clin Nutr ESPEN. 2018;25:63-7.

30. Singer P, Blaser AR, Berger MM, Alhazzani W, Calder PC, Casaer MP, et al. ESPEN guideline on clinical nutrition in the intensive care unit. Clin Nutr. 2019;38(1):48-79.

31. Thibault R, Seguin P, Tamion F, Pichard C, Singer P. Nutrition of the COVID-19 patient in the intensive care unit (ICU): a practical guidance. Crit Care. 2020;24:447.

32. Mechanick JI, Carbone S, Dickerson RN, Hernandez BJD, Hurt RT, Irving SY, et al. Clinical Nutrition Research and the COVID-19 Pandemic: A Scoping Review of the ASPEN COVID-19 Nutrition Taskforce. JPEN J Parenter Enteral Nutr. 2020;45(1),13-31. 
33. Martindale R, Patel JJ, Taylor B, Arabi YM, Warren M, McClave SA, et al. Nutrition Therapy in the Patient with COVID-19 Disease Requiring ICU Care. Reviewed and Approved by the Society of Critical Care Medicine and the American Society for Parenteral and Enteral Nutrition [Internet]. Published: 1 Apr 2020 [cited 2021 Feb 1]. Available from: https://www.sccm.org/ getattachment/Disaster/Nutrition-Therapy-COVID-19SCCM-ASPEN.pdf?lang=en-US.

34. Singer P, Berger MM, Van den Berghe G, Biolo G, Calder P, Forbes A, et al. ESPEN Guidelines on Parenteral Nutrition: intensive care. Clin Nutr. 2009;28(4):387-400.

35. Kreymann KG, Berger MM, Deutz NE, Hiesmayr M, Jolliet P, Kazandjiev G, et al. ESPEN (European Society for Parenteral and Enteral Nutrition). ESPEN Guidelines on Enteral Nutrition: Intensive care. Clin Nutr. 2006;25(2):210-23.

36. McClave SA, Taylor BE, Martindale RG, Warren MM, Johnson DR, Braunschweig C, et al. Society of Critical Care Medicine; American Society for Parenteral and
Enteral Nutrition. Guidelines for the Provision and Assessment of Nutrition Support Therapy in the Adult Critically Ill Patient: Society of Critical Care Medicine (SCCM) and American Society for Parenteral and Enteral Nutrition (A.S.P.E.N.). JPEN J Parenter Enteral Nutr. 2016;40(2):159-211.

37. Canadian Clinical Practice Guidelines Committee. Canadian Clinical Practice Guidelines. [Internet]. Published: 2017 Apr. Available from: https://www. criticalcarenutrition.com/docs/CPGs\%202015/4.1b(i). pdf.

38. Doaei S, Gholami S, Rastgoo S, Gholamalizadeh M, Bourbour F, Bagheri SE, et al. The effect of omega-3 fatty acid supplementation on clinical and biochemical parameters of critically ill patients with COVID-19: a randomized clinical trial. JTransl Med. 2021;29;19(1):128.

39. Asher A, Tintle NL, Myers M, Lockshon L, Bacareza H, Harris WS. Blood omega-3 fatty acids and death from COVID-19: A pilot study. Prostaglandins Leukot Essent Fatty Acids. 2021;166:102250. 